\title{
Dados e informação: significados e engajamento
}

\section{Data and information: meanings and engagement}

\author{
Patricia Zeni Marchiori ${ }^{1}$, Andre Luiz Appel ${ }^{2}$, Eduardo Michelotti Bettoni ${ }^{2}$ \\ ${ }^{1}$ Universidade Federal do Paraná - UFPR, Curitiba, PR, Brasil \\ ${ }^{2}$ Grupo de Pesquisa UFPR/CNPq - Metodologias para Gestão da Informação, Curitiba, PR, Brasil
}

Autor para correspondência/Mail to: Patricia Zeni Marchiori (editoratoz@gmail.com)

Copyright (c) 2016 Marchiori, Appel \& Bettoni. Todo o conteúdo da Revista (incluindo-se instruções, política editorial e modelos) está sob uma licença Creative Commons Atribuição-NãoComercial-Compartilhalgual 3.0 Não Adaptada. Ao serem publicados por esta Revista, os artigos são de livre uso em ambientes educacionais, de pesquisa e não comerciais, com atribuição de autoria obrigatória. Mais informações em http://revistas.ufpr.br/atoz/about/submissions\#copyrightNotice.

Este volume 5/número 2 da AtoZ apresenta quatro artigos e um short paper, além da tradicional entrevista com especialistas. A tônica dos trabalhos publicados segue uma tendência já percebida na dinâmica de recebimento, avaliação e eventual publicação de investigações: em maior ou menor grau os autores buscam extrair sentido e testar a efetividade de estratégias de engajamento de públicos-alvo diferenciados em distintos processos ligados à dados e à informação. A pesquisa de Silva e Martins, no âmbito da Universidade Federal de Goiás (UFG), descreve e analisa a realidade e a potencialidade da coautoria e internacionalização da produção científica na Instituição, que representa - em última instância - o impacto das pesquisas da UFG em audiências e parcerias externas. O engajamento, via tecnologia educativa, está presente na experiência de motivação, baseada no uso da “aula invertida”, relatada por Ruiz-Robles, junto a estudantes de inglês; e, no desenho, implantação e avaliação de cursos online baseados em objetos de aprendizagem, cuja experiência é relatada no short paper assinado por Zambrano e demais coautores.

Quanto ao papel das tecnologias para auxiliar na exploração de significados, Almeida e colaboradores exploram condições tecnológicas para aumentar a qualidade de volumes robustos de dados, assim como Sonego, Marcelino e Gruber verificam - via conexões da literatura - relações pervasivas da “Internet das Coisas” (IoT) com uma área de potencial aplicação (eficiência energética).

Todos os trabalhos publicados nesta edição (e em outras) da AtoZ apresentam resultados provenientes de coleta e tratamento de dados em distintos vieses metodológicos experimentais, quali-quantitativos ou de análise de redes sociais, por exemplo. O desafio de se armazenar, tratar e, especialmente, disponibilizar ao público os dados de pesquisa é o tema da entrevista gentilmente cedida pelos doutores Luis Fernando Sayão e Luana Farias Sales, os quais apresentam e detalham o estado da arte neste tema e os possíveis caminhos para os autores, gestores/curadores dos repositórios e os usuários interessados em reutilizar dados.

Foi também no decorrer da elaboração desse número, entre julho e dezembro de 2016, que o Projeto elaborado pela equipe gestora da AtoZ - e aprovado no Edital de Apoio à Editoração e Publicação de Periódicos Científicos (PRPPG/UFPR, 2016) - finalizou seus objetivos. Constituiu-se uma base de referências do material publicado na AtoZ (desde o número de estreia até o v. 5 n.1.), definindo-se e gerando-se indicadores de desempenho. Os resultados permitiram verificar que a base de dados de citações tem efetivo potencial para subsidiar indicadores e melhor compreender as relações da Revista com outras fontes de informação na área, o que permitirá - a médio prazo - avaliar a situação da AtoZ no macro cenário das revistas acadêmico-científicas. Ao se definir um conjunto de métricas de avaliação e testá-las resulta - de imediato - em apoio ao processo decisório do Corpo Editorial e, potencialmente, na exploração da metodologia proposta por outros editores interessados. $\mathrm{O}$ Projeto está na fase de submissão de relatório final e prestação de contas, motivo pelo qual o detalhamento dos resultados será objeto do próximo Editorial da Revista. Contudo, a trajetória metodológica, que inclui a especificação das fases de execução, se encontra disponível para consulta na base e-Lis. 